\author{
REVIEW OF EUROPEAN AND COMPARATIVE LAW \\ VOLUME XXXVIII \\ YEAR 2019
}

\title{
MINIMUM STANDARDS IN THE EUROPEAN ACCOUNT PRESERVATION ORDER
}

\author{
Mateusz Wiktor Golak*
}

\begin{abstract}
The article is devoted to minimum standards in the new procedural instrument - the European Account Preservation Order. The main purpose of the preservation proceeding is to grant an interim order of creditor's claim on debtor assets, without overburdening his property. Due to the complicated procedure established by Regulation (EU) No 655/2014, the European Account Preservation Order should serve as an additional and optional measure for the creditor, the examination of the minimum standards is essential. The Author indicates the relation between the above-mentioned regulation and other regulations and gives an explanation why this instrument is another symptom of the new EU legislator's approach to cross-border civil matters. Since the debtor is a person whose interests are most affected by the preservation of the bank account, it is necessary to specify his rights and obligations in these proceedings.
\end{abstract}

Key words: civil procedure, European Account Preservation Order, minimum standards, protective measure

\section{INTRODUCTION - THE CONCEPT OF UNIFORM PRESERVATION ORDER}

Considering the increased amount of cross-border civil and commercial cases, the role and importance of securing claims in these proceedings, it is therefore necessary to conduct a fundamental analysis of the

Adam Mickiewicz University in Poznań, Faculty of Law and Administration. 
new legal instrument - the European Account Preservation Order ${ }^{1}$. It was conceived as a very important element of the development of the EU civil procedure and as the Uniform Protective Order. The theoretical and practical attractiveness of the subject matter, combined with the lack of a broader discussion of the matter in Polish literature, makes it a fully justified argument for choosing this institution. Until recently, the above-mentioned issue has existed exclusively in the national law of a Member State. It is only in recent years that the development of the Internal market has forced the establishment of legislation within the European Union. The issue of swift and effective protective measures that are effective within the Union is very important in economic activity, particularly by the businesses in the Internal Market of the European Union. It also has implications for consumers who increasingly use cross-border services. It is necessary to indicate only minimum standards, whereas maximum standards are probably impossible to achieve in 28 different legal systems in all EU member states.

Since the last century there are certain principles which might be adopted by nations wishing to assume the Uniform Protective Order. Those principles adopt the essence of freezing injunctions and civil search orders. The best way of meeting this need for inter-jurisdictional coordination is to combine:

(1) an international uniform law of protective and ancillary relief which should be adopted by leading trading nations and gradually extended beyond such jurisdictions; and

(2) a reciprocal system of recognition of such judicial order - even when they are surprise remedies, made ex parte, or without notice to the respondent ${ }^{2}$.

The question is whether the model of the EAPO meets the requirements? In the two upcoming chapters of this paper, there is an attempt to answer this fundamental question. The presented article is, therefore, aiming to fill the gap that exists in the EAPO research in Poland and across the whole of Europe. The research should also answer the question if the

Hereinafter „EAPO”.

2 Neil Andrews, Provisional and Protective Measures: Towards an Uniform Protective Order in Civil Matters, Uniform Law Review - Revue de droit uniforme 6 (2001): 932. 
present European Account Preservation Order is balanced between rights of the creditor and the debtor. This topic refers to material that is very important in doctrinal and practical terms and in addition very intricate on the legal side, which has not yet reached its monographic development in Polish or European literature. In particular, there is no description of this issue in the context of legislative solutions used in other EU instruments (the European Enforcement Order for Uncontested Claims; the European Order for Payment Procedure and the European Small Claims Procedure). There have been few detailed analysis of the Regulation No $655 / 2014$ in the national literature, but none of them were dedicated to the minimum standards. The available study was issued before the date of application of the provisions herein and left this topic without deep analysis ${ }^{3}$. The state of research of the institution in foreign literature is also not exhaustive.

\section{INTERNATIONAL UNIFORM LAW OF PROTECTIVE AND ANCILLARY RELIEF}

In view of the ever-increasing level of free movement of goods, services, and judgments in civil matters in the European Union, cross-border protective measures may become a key element in the process of debt recovery from foreign counterparts. Thus, it was necessary under the European Union to create an instrument allowing the bank account to be secured in parallel with those provided for in the legal systems of the Member State for temporarily securing the receivables ${ }^{4}$. The Commission's Proposal on the preservation of bank accounts had three aims $s^{5}$ :

3 Alicja Aseńko, Transgraniczne zabezpieczenie wierzytelności na rachunku bankowym - nowe rozporządzenie (UE) 655/2014, Monitor Prawniczy 8 (2015) (dodatek): 37-41; Justyna Piasecka, Europejski nakaz zabezpieczenia na rachunku bankowym - nowy instrument prawny wprowadzony rozporządzeniem Parlamentu Europejskiego i Rady (UE) nr 655/2014, Przegląd Prawa Egzekucyjnego 9 (2017): 5-15.

Franz W. Urlesberger, Europarecht: Das Neueste auf einen Blick, Wirtschaftsrechtliche Blätter 23/4 (2011): 483.

5 Proposal for a Regulation of the European Parliament and of the Council Creating a European Account Preservation Order to facilitate cross-border debt recovery in civil and 
(1) to enable creditors to obtain account preservation order on the basis of the same conditions irrespective of the country in which the competent court is located;

(2) to allow creditors to obtain information on the whereabouts of their debtors' bank accounts;

(3) to reduce costs and delays for creditors seeking to obtain and enforce an account preservation order in cross-border situations.

Considering this scope The Regulation meets requirements to be an international uniform law of protective and ancillary relief. The issue of cross-border preservation order has been recognized by the EU legislator by providing a comprehensive legal instrument for both civil and commercial cases. Regulation (EU) No 655/2014 establishes a European Account Preservation Order procedure to facilitate cross-border debt recovery in civil and commercial matters ${ }^{6}$. There was a parallel initiative to issue an EU legislative act aimed at protective measures to ensure bank account freezing and to enhance the mere enforcement against the debtor's assets stage ${ }^{7}$. This Regulation does not provide for the establishment of a new way of enforcing monetary claims, but only for the preservation of monetary claims ${ }^{8}$. In recital 7 in the preamble to the Regulation (EU) No 655/2014 it is worth notice that a creditor should be able to obtain a protective measure in the form of the European Account Preservation Order preventing the transfer or withdrawal of funds held by his debtor in a bank account maintained in a Member State if there is a risk that, without such a measure, the subsequent enforcement of his claim against the debtor will be impeded or made substantially more difficult. This regulation has general application, is binding and directly applicable in all Member States, as stated in Article 288 of the Treaty on the Functioning

commercial matters, $\operatorname{COM(2011)~} 445$ final of 25 July 2011: 4.

6 The European Parliament and of the Council Regulation (EU) 655/2014 of 15 May 2014 establishing a European Account Preservation Order procedure to facilitate cross-border debt recovery in civil and commercial matters (2014) OJ L189/59.

7 Mirela Župan, Cross-border recovery of maintenance taking account of the new European Account Preservation Order (EAPO), ERA Forum 8 (2015): 169.

Alicja Aseńko, op. cit.: 1. 
of the European Union'. Since this Regulation is applicable in the European Union only from 18 January 2017, it is justified and highly valid to analyze this EU instrument. This law is nowadays adopted by all of the Member States except the Denmark. This country is not taking part in the adoption of this Regulation and is not bound by it or subject to its application.

\section{THE RELATION BETWEEN EAPO AND OTHER EUROPEAN REGULATIONS}

The initial purpose of the article is to question on the concept of a EAPO, its function and its relation to other European Regulations. The instrument is just another symptom of the new EU legislator's approach to cross-border civil matters in the form of full jurisdiction of the court of origin, based on the minimum standards of the regulation and including the abolition of exequatur ${ }^{10}$. The other elements are the European Enforcement Order for Uncontested Claims ${ }^{11}$, the European Order

9 Consolidated versions of the Treaty on European Union and the Treaty on the Functioning of the European Union, OJ C 326, 26.10.2012: 47-390.

${ }_{10}$ Maciej Taborowski, Wojciech Sadowski, Wybrane problemy stosowania rozporządzenia Nr 805/2004 w sprawie utworzenia Europejskiego Tytułu Egzekucyjnego dla roszczeń bezspornych, In: Współpraca sądowa w sprawach cywilnych i karnych, ed. Władysław Czapliński, Andrzej Wróbel, Warsaw: C.H. Beck 2007, 184.

${ }_{11}$ Regulation (EC) No 805/2004 of the European Parliament and of the Council of 21 April 2004 creating a European Enforcement Order for uncontested claims (OJ L 143, 30.4.2004, pp. 15-39); by means of the enforcement order: judgments, court settlements and authentic instruments on uncontested claims can be recognised and enforced automatically in another Member State, without exequatur. This regulation would not apply to any preservation measures because they do not fall within the scope of the term "judgment" in the light of Art. 4 point 1 Regulation (EC) No $805 / 2004$, while issued in the ex parte proceedings ( $c f$. Karol Weitz, Europe ski tytut egzekucyjny dla roszczeń bezspornych, Warsaw: Lexis Nexis 2009, 83-85). The principle rule under Article 11 of the Regulation 655/2014 is that the debtor shall not be notified of the application for a Preservation Order or be heard prior to the issuing of the Order. 
for Payment Procedure ${ }^{12}$ and the European Small Claims Procedure ${ }^{13}$. EU regulatory strategy considers the general abolition of exequatur proceedings as the next step of the integration of European procedural laws ${ }^{14}$. As a consequence, the EAPO is just a part of the whole new European concept, described implicitly in Article 22 of the Regulation No $655 / 2014$ as non-exequatur ${ }^{15}$. The EAPO is based on the procedures applicable to the enforcement of equivalent national orders in the Member State of enforcement.

It is also important to indicate the relationship between Regulation No 655/2014 and Regulation (EU) No 1215/2012 of the European Parliament and of the Council of 12 December 2012 on jurisdiction and the recognition and enforcement of judgments in civil and commercial matters ${ }^{16}$. Brussels I (recast) also establishes procedure of recognition and enforcement of the protective measures. The choice of the procedure belongs to the applicant, but it must be remembered that they are separable. Recognition and enforcement are carried out either on the basis of the Brussels (recast) or Regulation 655/2014. While looking for jurisdiction under Brussels I (recast) one option to the creditor is to grant a motion for a protective measure to the court having jurisdiction as to the sub-

12 Regulation (EC) No 1896/2006 of the European Parliament and of the Council of 12 December 2006 creating a European order for payment procedure (OJ L 399, 30.12.2006, pp. 1-32); regulation permits the free circulation of European order for payment which is recognised and enforced in all EU countries without any intermediate proceedings.

13 Regulation (EC) No 861/2007 of the European Parliament and of the Council of 11 July 2007 establishing a European Small Claims Procedure (OJ L 199, 31.7.2007, pp. 1-22); The Regulation ensures that judgments are recognised and enforceable in another Member State, without exequatur.

14 Draft multi-annual programme for the area of Freedom, Security and Justice, 16 October 2009, Doc. 14449/09: 4.

15 Explicitly: „A Preservation Order issued in a Member State in accordance with this Regulation shall be recognised in the other Member States without any special procedure being required and shall be enforceable in the other Member States without the need for a declaration of enforceability".

16 Regulation (EU) No 1215/2012 of the European Parliament and of the Council of 12 December 2012 on jurisdiction and the recognition and enforcement of judgments in civil and commercial matters, OJ L 351, 20.12.2012: 1; hereinafter: „Brussels I (recast)”. 
stance of the matter ${ }^{17}$. As EU Regulator mentions in recital 33 in the preamble to the Brussels I (recast): protective measures which were ordered by such a court without the defendant being summoned to appear can only be recognized and enforced unless the judgment containing the measure is served on the defendant prior to enforcement. Secondly, it should be noted that the creditor has been allowed to apply for a provisional protective measure also to the court which has no jurisdiction as to the substance of the matter. As per this article 35 Brussels I (recast) application may be made to the courts of a Member State for such provisional measures as may be available under the law of that Member State, even if the courts of another Member State have jurisdiction as to the substance of the matter. Neither provision contains any restrictions on lis pendens, nor excludes the preservation of a claim by a court other than the one before which proceedings are pending as to the substance of the matter ${ }^{18}$. As in the first option, the second one needs to provide the defendant with a ruling before its execution (Article 2 (a) of Brussels I recast). It approaches to not enough surprising effect, which is very important in securing monetary claims. But it challenges needs with regard to the protection of the defendant in cross-border litigation. The case-law of the Court of Justice on the interpretation of jurisdiction in protective measures creates an additional premise. The Court of Justice indicates that the granting of provisional or protective measures is conditional on, inter alia, the existence of a real connecting link between the subject-matter of the measures sought and the territorial jurisdiction of the Member State of the court before which those measures are sought ${ }^{19}$. What is more under recital 33 in the preamble to the Brussels I (recast) the effect of measures ordered by a court of a Member State not having jurisdiction as to the substance of the matter should be confined only to the territory of that Member State. In the latter case, the effect is limited due to avoid forum-shopping. It should be noted that definition of forum shopping

17 Alicja Aseńko, op. cit.: 2.

18 Decision of Court of Appeal in Poznań of 11 October 2017, case I ACz 1333/17, Portal Orzeczeń Sądów Powszechnych.

19 Judgment of the Court of 17 November 1998, case C-391/95, Van Uden Maritime $B V$, ECLI C 1998: 543. 
was made by Advocate General Léger as a decision of the applicant to bring his action in a particular court purely in order to benefit from the application of a law, or even of case-law, that is more favorable to the protection of his own interests, to the detriment of those of the defendants, and not in order to meet an objective need from the point of view of proof or the effective organization of the proceedings ${ }^{20}$. The minimum procedural standard relating to forum shopping is comprised in article 3 point 1 of Regulation No 655/2014. This provision states the definition of the cross-border case which prevents easy evasion from the national rules unfavorable to the creditor (enforce shopping) ${ }^{21}$.

The ambiguous regulation of Recital 8 of Regulation No 655/2014 requires a short examination. The scope of EAPO Regulation should cover all civil and commercial matters apart from certain well-defined matters. In particular, Regulation should not apply to claims against a debtor in insolvency proceedings. The widely differing national laws on security interests to be found in the Member States was acknowledged in recital 22 in the preamble to the new bankruptcy regulation ${ }^{22}$. Under this regulatory framework, there are two important issues of the relation between Regulation No 655/2014 and insolvency proceedings which should be indicated here. On the one hand, the EAPO should not apply to claims against a debtor in insolvency proceeding $s^{23}$. On the other hand, the exclusion should allow the EAPO to be used to secure the recovery of detrimental payments made by such a debtor to third parties. This regulatory approach entails the need for specific and comprehensive research which cannot be done in this paper due to its character and limited volume.

20 Opinion of Advocate General Léger delivered on 8 December 2005, case C-539/03, Roche Nederland BV vs. Primus and Goldenberg, C 2005, 749, point 96.

21 A. Aseńko, op. cit: 3.

22 Regulation (EU) 2015/848 of the European Parliament and of the Council of 20 May 2015 on insolvency proceedings, OJ L 141/19, 5.6.2015.

23 Verba legis: ... as defined in Council Regulation (EC) No 1346/2000, but Regulation (EU) 2015/848 repealed Regulation (EC) No 1346/2000. 
The essential part of this article is devoted to selected minimum standards covering by the Regulation No 655/2014. As well as the scope of rights of entities involved in EAPO proceedings, especially the procedurally weaker party - the debtor. According to B. Hess there are two ways of formulating minimum standards: on the one hand, they can be decided from constitutional or treaty principles. On the other hand, it is possible to find precise rules in the existing instruments of European procedural $\mathrm{law}^{24}$. With respect to minimum fundamental standards from the Charter of Fundamental Rights of the European Union ${ }^{25}$, the Regulation notably relied on the idea of safeguard the debtor's right to a fair trial and his right to an effective remedy (Recital 44).

The minimum procedural standards start with the conditions for issuing the Preservation Order. This should be strictly balanced between the interest of the creditor in obtaining an EAPO and the interest of the debtor in preventing abuse thereof. The recitals comply with regulation established by article 7 which requires submission of sufficient evidence to satisfy the court that there is an urgent need for a protective measure because there is a real risk that, without such a measure, the subsequent enforcement of the creditor's claim will be impeded or made substantially more difficult. As the Regulation does not detail how the „urgent need” and "real risk" should be proved by a creditor and measured by a court, there is there is a concern that different interpretations of these prerequisite standards will arise throughout the EU Member States ${ }^{26}$. However, it is helpful to ask the Court of Justice whose case law consolidates the application of EU law. Above-mentioned Recital indicates what should be taken into account by court: the debtors' conduct in respect of a claim; the debtors' credit history; the fact that there are more creditors; as well as the fact that mere non-payment or contesting of the claim should not

24 Burkhard Hess, "Towards minimum standards in European civil procedural law", In: Aurea Praxis. Aurea Theoria. Księga Pamiątkowa ku czci Profesora Tadeusza Erecińskiego, ed. Jacek Gudowski, Karol Weitz, Warsaw: Lexis Nexis 2011 (1): 1083.

25 OJ C 326/391, 26.10.2012.

26 Mirela Župan, op. cit.: 172. 
be considered sufficient evidence to justify issuing of an EAPO. As stated in Recital 14 the creditor should be required in all situations, including when he has already obtained a judgment, to demonstrate to the court that there is "urgent need" and "real risk". The clue point is that these two factors should be demonstrated through the evidence provided but not only verbalized $^{27}$. The real risk is a certain objective condition regarding the behavior of the debtor ${ }^{28}$. Whereas the creditor in a Member State has obtained a judgment that requires the debtor to pay the creditor's claim, the scope of protection of debtor should be more pursuant to creditor's rights (Article 7.1. Regulation). As opposed to the situation when the creditor initiates procedure for obtaining a preservation order before he initiates proceedings in a Member State against the debtor on the substance of the matter (Article 7.2 and Article 12 of the Regulation).

The other minimum standards set up by Regulation No 655/2014 concern the security to be provided by the creditor (Article 12), the liability of the creditor (Article 13), amounts exempt from preservation (Article 31) and remedies (Chapter 4). The debtor is safeguarded by article 12 which provides security for an amount sufficient to prevent abuse of the procedure if the creditor has not yet obtained a judgment. The bail judgment can, therefore, be considered as a rule in this procedure, which may not be applied by way of exception. The recitals give a comprehensive explanation for this new approach. These include: the creditor has a particularly strong case but does not have sufficient means to provide security; that the claim relates to maintenance or to the payment of wages; the size of the claim is such that the EAPO is unlikely to cause any damage to the debtor, for instance, a small business debt (Recital 18). The creditor should make probable the lack of sufficient means to provide security by the court. This exception might become a principle in maintenance cases $^{29}$. In case of small debts, the definition from the European Small Claims Procedure can be indirectly applicable, where the value of a claim

27 Decision of District Court in Bydgoszcz of 23 March 2017, case XII Co 1446/17, Portal Orzeczeń Sądów Powszechnych.

28 Decision of Court of Appeal in Katowice 22 May 2018, V AGz 317/18, Portal Orzeczeń Sądów Powszechnych.

29 Mirela Župan, op. cit: 173. 
does not exceed 5000 EUR nowadays ${ }^{30}$. Where the creditor has already obtained a judgment, security is an optional instrument to the court-connected with necessity and appropriateness in the circumstances of each case (Article 12.2). Even if the debtor provides the security, there should be no issue of the EAPO when the conditions for its issuance as set out in Article 5 in conjunction with article 7(1) of Regulation No 655/2014 are not met $^{31}$.

Article 13 has been framed in the light of the relatively valid burden of proof in respect of the liability of the creditor for the damage caused to the debtor by the Preservation Order due to fault on the creditor's part and the mandatory presumptions of the creditor's fault. Whereas the burden of proof lies with the debtor, the Regulation points towards four facts that have to be taken into account to the presumed liability of the creditor (Article 13.2). The catalogue is open for national law to establish grounds for liability and types of liability other than those specified in this Regulation. Polish legislators did not decide to introduce additional premises in Polish civil procedure $\mathrm{law}^{32}$. The premises in Regulation are mostly related to creditor's inappropriate behavior, which is:

(1) revocation of the EAPO due to failure to initiate proceedings on the substance of the matter, unless that omission was a consequence of the debtor's payment of the claim or another form of settlement between the parties;

(2) negligence of the obligation to release over-preserved amounts as provided for in Article 27;

(3) founding that the issue of the Order was not appropriate or appropriate only in a lower amount due to a failure on the part of the creditor to comply with his obligations under Article 16;

30 Regulation (EU) 2015/2421 of the European Parliament and of the Council of 16 December 2015 amending Regulation (EC) No 861/2007 establishing a European Small Claims Procedure and Regulation (EC) No 1896/2006 creating a European order for payment procedure, OJ L 341, 24.12.2015: 1-13.

31 Decision of Court of Appeal in Katowice 22 May 2018, V AGz 317/18, Portal Orzeczeń Sądów Powszechnych.

32 Cf. art. 1144(3) - art. 1144(13) Polish civil procedure code (Act of 15 December 2016, Dz. U. 2017, pos. 85). 
(4) revocation of the EAPO or its enforcement terminated due to failure to comply with obligations under this Regulation with regard to service or translation of documents or with regard to curing the lack of service or the lack of translation.

The minimum standards of remedies contained in the Regulation are very detailed. Chapter 4 describes several different modes of remedies of the debtor against an EAPO. There is not enough space in this article to explain every single part of its structure. While it should be a reason for another such a publication, it is necessary to indicate some of the remarks about remedies. The Regulation divides remedies into two types: first upon application by the debtor to the court of origin and second upon application to the court of enforcement. This approach is characteristic of the European Union regulations, such as the European Enforcement Order. The debtor has the right to grant a motion for revocation or modification of an EAPO to the competent court of the Member State of origin. The most essential remedies are based on the prerequisite of an EAPO issuing (point an of Article 33.1). This provision makes it possible in principle to verify the basis for the issue ${ }^{33}$. Remedies by Article 33.3\&4 are connected to the validation of service. The debtor's remedies against enforcement of the Preservation Order are limited to the amounts in accordance with Article 31(2) and Article 31(3). These amounts exempt from preservation are connected with national law of the Member State of enforcement which regulates its seizure. The Regulation provides for a minimum standard aimed at the request from the debtor to exempt amounts in seizure under national law from preservation. Specific provisions are provided for by point (a) of Article 34(1) of the Regulation. There are four termination grounds which are divided as follows: the scope of application of the Regulation, a refusal to issue the Preservation Order, suspension of the enforceability of the judgment and other indicated by point b (iv) Article 34.1. Last but not least, Regulation states the public-policy clause. Pursuant to Article 34.2. the enforcement of the Preservation Order would be terminated if it is manifestly contrary to the public policy of the Member State

33 Marcin Walasik, Europejski nakaz zabezpieczenia na rachunku bankowym, na tle prawa krajowego, In: Egzekucja Sądowa w Świetle Przepisów z Zakresu Międzynarodowego Postępowania Cywilnego, ed. Andrzej Marciniak, Sopot: Currenda, 2016, 244. 
of enforcement. The Court of Justice does not define the content of the public policy but is competent to review the limits within which the courts of a Member State may have recourse to the concept of the public-policy clause for the purpose of refusing recognition to a judgment emanating from a court in another Member State ${ }^{34}$.

Finally, there is no down transference of an application for remedies. Just both parties have the right to appeal to the court of the second instance against a decision issued pursuant to Article 33, 34 or 35, under following article 37 of the Regulation. It is worthy of notice that the Regulation does not indicate a specific time limit for presenting an objection against EAPO. The statutory time limit for the decision revoking, modifying, limiting or terminating the Preservation Order is very restricted - without delay, but no later than 21 days after the court has received all the necessary information. What is more such, a decision is enforceable immediately.

\section{CONCLUSION}

The fresh issuing of the EAPO requires verification that the minimum standards collected above have been respected by the Member States. The unquestionable influence of the courts on this matter will, in the course of the research carried out in the future, lead to the sharing of experience and support for the interpretation of the provisions of the European Union regulations applicable in other cases by the courts of the Member States. The assembly, use, and dissemination in this field of judicature of the courts of the Member States and of the Court of Justice shall not be overestimated. For the time being there is only one published decision of the Polish court under Regulation 655/2014 and no pertinent case law of the Court of Justice.

34 Judgment of the Court of 28 March 2000, case C-7/98, Krombach, par. 23; more about the public-policy clause in case law of CJ - Agnieszka Knade-Plaskacz, Naruszenie klauzuli porządku publicznego i pozbawienie strony możliwości obrony jako przesłanki odmowy uznania orzeczenia zagranicznego w sprawach cywilnych i handlowych w świetle orzecznictwa Trybunału Sprawiedliwości, Europejski Przegląd Sądowy 3 (2015): 34-39. 
As has been shown above, the present EAPO Regulation performs certain principles that should be adopted across the European Union wishing to assume a Uniform Protective Order. The Regulation 655/2014 is binding in its entirety and directly applicable in all Member States. A vast catalogue of remedies is a crucial element of minimum standards. As B. Hess mentioned "for everyday business (and litigation) it seems to be more useful to implement precise standards directly into the specific procedural laws" ${ }^{35}$. Even The Regulation establishes ex parte proceedings, a reciprocal system of recognition of the EAPO is framed (abolition of exequatur proceedings under Article 22). It has been demonstrated that precise minimum standards in the existing instrument of European procedural law are possible to find. On the one hand, there are plenty of the conditions for issuing the Preservation Order, on the other hand, the Regulation points towards catalogue of remedies. There has also been indicated the procedure of extraordinary review in the Member State of enforcement the EAPO. It should be noticed that the stricter requirements for the granting of the EAPO and the need for the creditor to provide security may deter many, including smaller businesses, from applying for the Preservation Order. All in all, the present European Account Preservation Order is balanced between the rights of the creditor and the debtor. It fills the gap in the creditor's protection left open by the Brussels I (recast) which has unnecessarily abolished the surprise effect ${ }^{36}$. Then again, it is accompanied by procedural safeguards protecting the rights of the debtor.

\section{REFERENCES}

Andrews Neil. 2001. Provisional and Protective Measures: Towards an Uniform Protective Order in Civil Matters, Uniform Law Review - Revue de droit uniforme 6: 931-949.

35 Burkhard Hess, op. cit.: 1085.

36 Burkhard Hess, Katharina Raffelsieper, "Die Europäische Kontenpfändungsverordnung: Eine überfällige Reform zur Effektuierung grenzüberschreitender Vollstreckung im Europäischen Justizraum", IPRax. Praxis des Internationalen Privat- und Verfahrensrechts 1 (2015): 46. 
Aseńko Alicja. 2015. Transgraniczne zabezpieczenie wierzytelności na rachunku bankowym - nowe rozporządzenie (UE) 655/2014, Monitor Prawniczy 8 (dodatek): 37-41.

Hess Burkhard. Katharina Raffelsieper. 2015. Die Europäische Kontenpfändungsverordnung: Eine überfällige Reform zur Effektuierung grenzüberschreitender Vollstreckung im Europäischen Justizraum. IPRax. Praxis des Internationalen Privat- und Verfahrensrechts 1: 46-52.

Hess Burkhard. 2011. Towards minimum standards in European civil procedural law. In: Aurea Praxis. Aurea Theoria. Księga Pamiątkowa ku czci Profesora Tadeusza Erecińskiego. Ed. Jacek Gudowski, Karol Weitz, 1:1081-1010. Warsaw: Lexis Nexis.

Knade-Plaskacz Agnieszka. 2015. Naruszenie klauzuli porządku publicznego i pozbawienie strony możliwości obrony jako przesłanki odmowy uznania orzeczenia zagranicznego w sprawach cywilnych i handlowych w świetle orzecznictwa Trybunału Sprawiedliwości, Europejski Przegląd Sądowy 3: 34-39.

Piasecka Justyna. 2017. Europejski nakaz zabezpieczenia na rachunku bankowym - nowy instrument prawny wprowadzony rozporządzeniem Parlamentu Europejskiego i Rady (UE) nr 655/2014, Przegląd Prawa Egzekucyjnego 9: 9-44.

Taborowski Maciej. Wojciech Sadowski. 2007. Wybrane problemy stosowania rozporządzenia Nr 805/2004 w sprawie utworzenia Europejskiego Tytułu Egzekucyjnego dla roszczeń bezspornych. In: Współpraca sądowa w sprawach cywilnych i karnych. ed. Władysław Czapliński, Andrzej Wróbel, 133-184. Warsaw: C.H. Beck.

Urlesberger Franz W. 2011. Europarecht: Das Neueste auf einen Blick. Wirtschaftsrechtliche Blätter 23:480 484. DOI: 10.1007/s00718-011-0052-3.

Walasik Marcin. 2016. Europejski nakaz zabezpieczenia na rachunku bankowym, na tle prawa krajowego. In: Egzekucja Sądowa w Świetle Przepisów z Zakresu Międzynarodowego Postępowania Cywilnego. ed. Andrzej Marciniak. 203-247. Sopot: Currenda.

Weitz Karol. 2009. Europejski tytuł egzekucyjny dla roszczeń bezspornych. Warsaw: Lexis Nexis.

Župan Mirela. 2015. Cross-border recovery of maintenance taking account of the new European Account Preservation Order (EAPO)". ERA Forum 16: 163-179. DOI:10.1007, 12027-015-0397-9. 
